\title{
REVIEW ESSAY: SUNSTEIN, STATUTES, AND THE COMMON LAW - RECONCILING MARKETS, THE COMMUNAL IMPULSE, AND THE MAMMOTH STATE
}

\author{
Peter L. Strauss*
}

After the Rights Revolution: Reconceiving the RegulaTORY STATE. By Cass Sunstein. Cambridge: Harvard University Press. 1990. Pp. xi, 284. \$25.

Professor Cass Sunstein's new book, After the Rights Revolution: Reconceiving the Regulatory State, builds upon, and in important ways seeks to integrate, much of Professor Sunstein's work over the past several years. He has been one of our most prolific and influential writers on issues of governmental structure, approaching the subject both from more or less conventional administrative law perspectives ${ }^{1}$ and from the constitutional perspectives of separation of powers. ${ }^{2}$ His work has dealt with a tension often addressed in the literature, that between the eighteenth-century Madisonian constitutional engine of limited, internally checked government and the realities of our sprawling contemporary structures. A particular contribution of Sunstein's has been to insist on bringing forward the Madisonian visions, on their accommodation, not their abandonment. This contribution entails rather vigorous disagreement with the economics-driven theorists of public choice, on the right, and those of deconstructionism, on the left. Sunstein wants to build a conceptual framework for contemporary government that embraces the Madisonian ideal of government structured to serve genuinely public ends in face of the risk of faction; that vision entails both reaching agreement on appropriate distinctions between public and private ends, and finding effective contemporary expression of such ideas as "checks and balances."

The "rights revolution" that presents the challenge with which Sunstein is concerned begins with the changes conventionally grounded in the New Deal and culminates in the rights explosion of

* Betts Professor of Law, Columbia University. A.B. 1961, Harvard; LL.B. 1964. - Ed. Thanks to Cynthia Farina, Eben Moglen, Henry Monaghan, Richard Pierce, and Roy Schotland, who read earlier drafts, and to the Abraham N. Buchman Fund for Administrative Law.

1. See, e.g., Sunstein, Standing and the Privatization of Public Law, 88 Colum. L. Rev. 1432 (1988); Sunstein, Reviewing Agency Inaction After Heckler v. Chaney, 52 U. CHI. L. REV. 653 (1985).

2. See, e.g., Sunstein, Beyond the Republican Revival, 97 YALE L.J. 1539 (1988); Sunstein, Constitutionalism After the New Deal, 101 HARV. L. REV. 421 (1987). 
the 1960s and 1970s - an explosion of environmental as well as civil rights. The role of government has expanded: no longer merely the antagonist to the citizen, the source of legal constraint, it now protects and promises her benefits as well. Laissez faire and minimal government have been replaced by welfare economics and pervasive government; the implicit assumption that the common law provides a prepolitical baseline of individual relations has been replaced by a disposition to regard all law, common and statutory, in terms of both the social ends it seeks and those it achieves. These recent developments could be perceived, at least by the already powerful, to have moved government even more profoundly into the lives of citizens, regulating not only activity in the economic marketplace but also what might seem to be more private preferences for such tastes as risk, beauty, recreation, and social milieu. ${ }^{3}$

Although Sunstein tells us that After the Rights Revolution is aimed at the influential attacks of the Reagan and Thatcher administrations on government regulation (p. 1), one might imagine a stimulus rather closer at hand. His University of Chicago colleagues and the scholarship on which they base their approaches stalk the footnotes that describe the analyses to which this book is a response. ${ }^{4}$ They are for a minimalist state, believing that government intervention must inevitably be inferior to market ordering supported by the common law; he supports a richer mix between government intervention and individual autonomy. Acknowledging that regulation often fails, Sunstein seeks to demonstrate that market ordering must often fail as well - that regulation is justified by ends a polity could properly seek and could not expect to occur without government intervention. In its sweep, this is an extraordinary, and I think correct, ambition. Few problems facing the scholar concerned with issues of government structure are more important or difficult than reconciling the size and ambition of contemporary government with the founders' insistence on balance and constraint, or finding a way past the grim political accounts of government offered by the right and the left to a statement that leaves room for genuinely public ends of action.

The initial chapters of the book sketch the growth of American regulation and attempt to assess its recent performance. Drawing on broad and effective reading of recent economic literature, Sunstein

3. Examples include laws requiring the provision of seat belts (and, more recently, their use), controlling outdoor advertising on highways, preferring low-impact to mechanized incursions on public lands, and prohibiting racial and other discriminations in private behavior. It is exactly Sunstein's point that, for the powerful, law has always regulated these matters to their advantage; to take only the most obvious example, it would strike a black person as odd to claim that law first became involved with private discriminatory behavior in 1964 . The advantaged, nonetheless, may not have noticed having their preferences regulated - shaped into some form they would not personally have chosen - until in the 1960 s.

4. E.g., Intro. nn. 2,4 ; ch. 2 nn.1, 41-43. 
seeks to refute the general critique of the regulatory enterprise, and to establish its general success. He acknowledges that particular failures have occurred - often attributing them, rather as Stephen Breyer did, 5 to inappropriate matches between public ends and the means chosen to implement them. For Sunstein, however, these failures are not finally determined by the fact of faulty legislative consideration (or, perhaps, legislative action distorted by the partial successes of private-interest-seeking factions). Postenactment interpretation can contribute significantly to the success or failure of regulation by identifying the public ends of legislation and building upon them.

Thus, Sunstein's eventual focus in this account (one imagines others will be forthcoming) is on the courts and the problem of statutory interpretation. For the courts, the issue posed by the rights revolution may be described as finding ways past "norms that are a legacy of the common law or that misconceive the values, functions, and failures of the regulatory state" (p. 160). Sunstein's way is to suggest a series of interrelated canons or interpretive principles for courts to apply; these, he asserts, will better secure legislation's public ends than does the common law canon. ${ }^{6}$

Consider as an example a state workers' compensation law that makes no provision in terms for the case in which an employer discharges a worker in retaliation for the worker having filed a claim under the law. Workers who understand that they will lose their jobs should they file claims are less likely to do so. That gives rise to the question whether the statute should be understood as requiring protection against such discharges. The common law generally follows the rule that employment is "at will" and, absent an implication from the statutory scheme, would provide no relief.

One could not argue ... that purely as a logical matter, a workers' compensation statute resolves the ambiguity. But the "deals" approach [treating legislation as the outcome of private-interest-group negotiation, and consequently entitled to no generative force] depends on the view that legislative silence on freedom to discharge should be understood as a resolution of the question, when it might merely mean inadvertence, failure to focus on the issue, or a delegation to the courts. The "deals" approach also depends on reflexive incorporation of common law principles as the baseline against which to read statutory silence, when the relevant baseline is the question to be decided. Some value judgment, informing legislative silence, must be made either way. [p. 208]

An interpretive strategy consistent with the public values that underlie such legislation, he argues, would understand that "[b]ecause discharge would interfere significantly with the program, the proper con-

5. S. BReyer, Regulation AND Its Reform (1982).

6. The bulk of this part of his analysis recently appeared in the Harvard Law Review. Sunstein, Interpreting Statutes in the Regulatory State, 103 HARV. L. REV. 405 (1989). 
clusion is that employers cannot discharge employees for filing claims" (p. 208).

This brief passage suggests the attractive strengths of Sunstein's elaborately argued and broadly read thesis. As in his other work, he offers theory in the context of institutions as they exist in fact. Here, he gives us a legislature that is, and only can be, imperfectly attentive or expressive. He also presents a careful and imaginative reading of the cases suggesting the common law baseline from which traditional courts proceed. In discussing statutory interpretation, as in his general account of regulation and its critics, Sunstein identifies the important voices, presents their positions with understanding and clarity, and crisply states his own view. The general thrust of his work, that courts interpreting statutes have an obligation to carry forward their public purposes in preference to the received traditions those statutes change, has a lineage extending back at least as far as Pound, ${ }^{7}$ Stone, ${ }^{8}$ and other major figures of the Progressive era. They, too, faced the propositions that the common law was inherently wise, and that statutes were to be treated with suspicion rather than as generative sources of policy judgment; and they generated forceful arguments why, in a democratic society, a more sympathetic approach was required. ${ }^{9}$ It is striking to find these arguments having to be repeated.

The following pages principally address Professor Sunstein's basic argument for building on, rather than defending against, legislative judgments, and so virtually ignore the details of his proposals for statutory interpretation. ${ }^{10}$ Part I outlines Sunstein's case for some regulation - the necessary failures of market ordering and the consequent need for a mixed economy in which government regulation intervenes

7. Pound, Common Law and Legislation, 21 HaRv. L. Rev. 383 (1908).

8. Stone, The Common Law in the United States, 50 HARV. L. REV. 4 (1936).

9. Stone and Pound might not, however, have viewed the worker's compensation example as an instance of statutory interpretation, as such. Desirable as interpretation generous to legislative purposes was to them, in their lexicon "interpretation" referred only to statutory text. Full reception of a statute into the body of the law implied, also, that it was to be "reasoned from by analogy the same as any other rule of law" - preferably, Pound argued, "as a later and more direct expression of the general will, of superior authority to judge-made rules on the same general subject." Pound, supra note 7, at 385 . Sunstein's example is much more readily understood as reflecting such a common law use of statutes than as interpretation per se.

10. Two colleagues have trenchantly questioned the workability in practice of those proposals, criticisms with which I largely agree, in an article responding to Sunstein's Harvard Law Review analysis, supra note 6. Moglen \& Pierce, Sunstein's New Canons: Choosing the Fictions of Statutory Interpretation, 57 U. CHI. L. REV. 1203 (1990); Professor Sunstein's characteristically disarming response appears as Sunstein, Principles, Not Fictions, 57 U. CHI. L. REV. 1247 (1990). The basic problem they identify with Sunstein's recommended new canons for interpretation, viewed simply as a collection of aids, is this: as subtle and deeply considered as they are, they entail a complexity and conceded indeterminacy that will present difficult challenges to all judges, and offer little impediment to the magistrate who is also a politician. It seems more appropriate to view them not as a new set of black-letter rules, in the style of the formalist approaches Sunstein essentially spurns, but as exemplars of a reasoning style that begins with the proposition that statutory law is entitled to sympathetic and thus progenitive implementation. 
in important ways. Part II addresses Sunstein's decision to tie his analysis to the public law innovations of the New Deal, and suggests ways in which the analysis might be strengthened by attention to earlier struggles and changes - changes in common law as well as statute law, in markets as well as legal response - brought about by the emergence of a complex, national economy.

Sunstein's analysis substantially depends on the proposition that public purposes can reliably be distinguished from rent-seeking purposes, and yet he seeks to avoid having to choose between two possible justifications for giving legislative actions generative force: that they may reflect genuinely collective action entitled to respect in a democratic order; or that they may, in particular cases, reflect the public good. Part III suggests ways in which the elision of these two bases for respect may prove problematic. Part IV takes up two problems not directly confronted in Sunstein's analysis, the enormous growth of contemporary government and the difficulties we face in theorizing about human behavior in ways that account for both our collective and our individualistic instincts, and seeks to illustrate these problems by recasting the questions of statutory interpretation in the context of historical development. Finally, Part V suggests that Sunstein has not been sufficiently attentive to problems generated by his describing as "rights" those claims for governmental action lacking the characteristic Holmes once identified as central to the availability of due process protections - that the claimants would be "exceptionally affected, in each case upon individual grounds." 11 The powerful can go to court as easily as to political institutions, and turning collective interests into "rights" suggests the creation of potentials for blocking governmental action that require careful consideration.

I.

At its most fundamental level, Sunstein's book presents an argument for the status quo, a mixed economy in which government regulation influences markets in important ways. From one perspective it is rather surprising that Sunstein must defend the status quo against arguments that the nation as a whole might be better served by a return to the principles of laissez faire. One had thought that the struggle between the minimalist governmental intervention suggested by the nineteenth-century common law and proactive government was the principal domestic political battle waged from the Civil War up to the 1930s, and that the issue was decided then. The need for regulatory intervention seems greater today, as fish disappear from our seas and streams, and ozone from the air; and as we become aware of the extent to which our past history of discrimination still orders our pres-

11. Bi-Metallic Inv. Co. v. State Bd. of Equalization, 239 U.S. 441, 446 (1915). 
ent lives. The notion appears risible that an invisible hand significantly responsible for elements of these troubles will lead us to the best available remedy, if only we will leave it undisturbed. Yet from another perspective, the return to influence of these ideas itself may suggest something about human nature, about the nature of the debate, or about the character of the intellectual enterprise that would be worth attending to.

Sunstein's analysis is grounded in appreciation of the mixed economy, our inheritance from the New Deal he celebrates. His fundamental premise is that we require both government and freedom; each has limits in its potential contribution to human good that makes too much of it undesirable. The critics with whom Sunstein is principally concerned are those of the right, whose use of economic and political science theories grounded in the premise that human beings invariably act out of rational self-interest produces a distorted view of human nature and a grim view of the possibilities of government. He understands that he must also meet criticism from the left - in particular (for an enterprise centered on the problem of interpretation), its claims regarding the indeterminacy of language and the irreducibly political dimensions of law. It is unlikely, however, that the left will see such questions as "Why Regulation?" (ch. 1) as serious ones, and the examples he repeatedly employs to suggest positive answers to those questions - discrimination avoidance, environmental protection, promotion of worker safety - will find easy support among left scholars. On the whole, collectivism is a left enterprise, and what Sunstein defends in the mixed economy is the collectivist part of the mix. Given the global retreat from collectivist enterprises over the past few years of political history, Sunstein seeks to remind us that the unregulated market is equally unreliable as a source of justice and to defend the claim that, at least occasionally, government can significantly improve upon the market's performance.

In broad outline, the argument is as follows: Although the initial Constitution (notably the Bill of Rights, but also such structural arrangements as the separation of powers) was centrally concerned with preventing collective interference with private ordering, government was also called upon to protect life, liberty, property, and contract from private aggression - a regulatory function initially carried out, on the whole, through the common law. As a legal system for achieving these ends, the common law of the nineteenth century embodied much of the structure of laissez-faire. That it succeeded in achieving its regulatory ends without requiring a visible governmental or bureaucratic apparatus "gave the nation a definite albeit misleading sense of statelessness" (p. 18). Yet the common law is not the ordained means for protecting life, liberty, property, and contract from private aggression, and the legislature may select alternative means - and alternative premises about what constitutes aggression - for doing so. 
"Seeing the common law status as prelegal and neutral, judges (and many others) did not recognize its principles as part of a regulatory system at all, but regarded them instead as the state of nature" (p. 19). Hence, the mistake of Lochner v. New York, ${ }^{12}$ undone during the New Deal by "a number of Supreme Court decisions treating the common law as a controversial regulatory system and as subject to democratic change" (p. 20). The Constitution, after all, did not enact Mr. Herbert Spencer's Social Statics. ${ }^{13}$

This "democratic change" has produced an explosion of new "rights," some of which are easier to understand as communal than as strictly personal in character: rights to protection from discrimination, to clean air and water, to safety at work, in our cars, or at home, to medical care, to retirement income, and to welfare. The laws protecting these interests can be understood, at least in retrospect, as illustrating ways in which simple reliance on the operation of a market will not inevitably generate outcomes politically identified as contributing to the common good. Sunstein points out three broad ways in which market ordering is likely to fail and which legislative regulation might be able to correct:

First, market mechanisms accept as given the existing distribution of resources, and other factors "that are morally arbitrary. . . There is no good reason for government to take these factors as natural or fixed, or to allow them to be turned into social and legal advantages, when it is deciding on the appropriate scope of regulation" (p. 39). "[T] he minimal state, distributing basic entitlements, has a range of consequences for, indeed constitutes, the distribution of rights, wealth, and power ... [which] in turn affects private preferences and beliefs. In this respect, it is not neutral ..." (p. 45).

Second, market mechanisms cannot surmount - indeed, in an important sense they contribute to - collective action problems such as the prisoner's dilemma. This characteristic tends to favor smaller groups already commanding resources over the more numerous public. Politics and law provide means to overcome these problems. For example, although wage and hour legislation is commonly seen as an attempt to redistribute wealth between employer and employee, it might instead be understood as a means employees chose among themselves to deal with a collective action problem they otherwise face in seeking employment (without necessary regard for any effect on employers' wealth). Seen this way, wage and hour statutes "facilitate the satisfaction of private desires, and do not override them at all" (p. 45).

Finally, markets do not self-correct for information failures or the effects of existing injustices that make apparent private preferences suspect. One obvious setting for such failures is workplace safety, where market forces tend to penalize the spontaneous generation of information revealing risk. Less obvious, perhaps, is the way in which market

12. 198 U.S. 45 (1905).

13. Lochner, 198 U.S. at 75 (Holmes, J., dissenting). 
forces rely on preferences or tastes that may themselves be the product of contestable social or legal arrangements. A taste for discrimination, among whites, or an apparent willingness to accept subordinate positions, among minorities or women, may in significant respects be "a product of available opportunities, which are a function of legal rules . . . allocat[ing] rights and entitlements" (p. 41). At its most simple, "when preferences are a function of legal rules, the rules cannot, without circularity, be justified by reference to the preferences" (pp. 41-42). Law may be chosen to affect preferences, to remedy prior injustice, or, more simply, to express "collective aspirations or considered judgments" (p. 46). Indeed, as the relevant market will function on a different basis once information has been digested or law-influenced preferences changed once, for example, social expectations about smoking in public places have been altered - any concern that intervention with market forces will prove futile appears misplaced. "If the preference is itself a function of the legal rule, or of current consumption patterns, legal barriers will not be circumvented, for the preference in question will be diminished or eliminated" (p. 44).

It does not follow that governmental interventions are invariably either sound or preferable to solutions relying on market ordering. Sunstein presents the case for a mixed economy not total control, and repeatedly emphasizes that government can fail, and that a system having freedom of contract, private property, and other provisions for reliance on voluntary arrangements "has the crucial advantage of respecting and fostering diverse conceptions of the good, an important part of individual freedom; it will promote economic productivity as well" (p. 46). Sunstein thus does not assert that government is not obliged to respect the integrity of existing distributions - that it could, for example, simply abolish private property. His is the more limited, and less controversial, claim that government need not respect the advantages that existing patterns of wealth create in various markets; it may, for example, regulate political campaign finances. If other values limit the extent of regulation (freedom of speech, for example - a value not necessarily associated with the preservation of economic power),${ }^{14}$ the effect is only to underscore the ways in which the existing distribution of resources serves as a morally arbitrary advantage in the legal system.

Sunstein's case for the status quo - against the minimalist state of laissez faire and for "a relatively large set of regulatory programs" ( $p$. 45 ) - is well put. Central to the analysis is a striking and important point, that today's legal order remains tied to the common law as the common law was before the emergence of the regulatory state, and in ways that cloak its political premises. Because the premises of that law conflict with the premises of a mixed economy to which both regu-

14. But cf. Lawrence, If He Hollers Let Him Go: Regulating Racist Speech on Campus, 1990 DUKE L.J. 431. 
lation and markets are central, treating that body of law as the ground for legal reasoning tends to retard the effectiveness of current legislative enterprises. Understanding that common law grounded in laissez faire is not a neutral given, but rather the embodiment of a contestable set of economic-political premises, permits embracing the political accomplishments of the New Deal conceptions not as elaboration or embroidery upon those premises - something to be reconciled with them - but as displacing them. Once we have accepted this displacement, our intellectual task vis-à-vis the common law heritage becomes determining what to keep in a legal order centered elsewhere. Similarly, the intellectual task vis-à-vis regulation becomes understanding how we can ensure its success. ${ }^{15}$ It is, in other words, the common law that must be reconciled, and law school curricula or judicial analyses that keep it at the center practice Ptolemaic astronomy.

II.

Among the deeper structures of the book are a number of premises that, although not central to Sunstein's ultimate interpretive enterprise, merit examination. One is that "public law" and "private law" are separable categories, so that the developments Sunstein examines all concern "public law." A second is that the relevant events to which we need to adjust ourselves - the "rights revolution" - are events of law formation, the sudden outpouring of statutes establishing regulatory regimes that began shortly after the election of Franklin Delano Roosevelt. A third (I am less sure whether this comes from Sunstein or whether I brought this to the reading) is that the common law in contemporary analyses, to which regulation is opposed, remains the constitutional founders' common law - a body of principles grounded in laissez faire and private ordering; correspondingly, the market remains the founders' market, one of individuals dealing capably face to face with their neighbors about goods generally within their ken.

Suppose that we took seriously the proposition that law is not autonomous - not in Posner's sense, that it lacks an intellectual center

15. Professor Roy Schotland of Georgetown, responding to a draft of this essay, remarked that Lochner serves no less as a metaphor for a more complex reality than does the New Deal. Eighteenth-century common law embraced a good deal of "regulation" (concerning, for example, inn keepers), as at least the Hamiltonians among the Constitution's drafters embraced regulation as well. Laissez faire notions find explicit mention in the analyses of Lord Abinger, Lemuel Shaw, and others reacting to the Industrial Revolution, and compete against continuing recognition that regulation is well justified for businesses "affected with a public interest." Munn v. Illinois, 94 U.S. 113, 126 (1877). "Adam Smith wrote precisely because at that time, so much law was, for so long, so far from laissez faire. Sunstein seems to me (and by my lights, you fall into his vision on this) to have gotten unduly wrapped up in Lochner; in doing so he's made a significant contribution that I don't mean to deny or at all diminish. But he's overlooked or underplayed the extent to which the Lochner vision is injuriously blind about earlier times and earlier law." Letter of Dec. 10, 1990, on file with the author. 
as compared to, say, economics, but in Holmes' terms, that it reflects not logic but experience. The proposition, then, is that law is not autonomous of our culture; like our language and our political or economic behavior, it is situated in and influenced by the world within which it exists, in ways that cannot be escaped. One can still believe that a subject exists, that law can be studied, illuminated, moved, in the same way that one can believe there is a subject of literary criticism worth pursuing even after establishing that language is inevitably contextual and that it is no more possible for reader than writer to escape that context. ${ }^{16}$ The belief arises, at least in part, from our experience/faith that the obverse is also true, that the seething brew of behaviors in the culture we happen to share is also not autonomous, but the product of what has gone before, including its language, its laws, and so forth, and that the understandings we happen to reach about these matters will shape the experiences of the future. And it is at least in part true because of our experience/faith that doing the best we can to understand prior events, even if we can do no more than approximate, will bring us closer to a capacity to understand our present or move the future.

Were we to take such a course, then the important phenomenon to consider, in worrying about the New Public Law, would be less legal changes themselves - the New Deal efflorescence of regulatory statutes that begins Sunstein's rights revolution - and more the cultural, social, political, and economic changes that set their context. This is hardly a new point; it was central to the work of Legal Realists, prominently of Karl Llewellyn, whose chair Sunstein holds. Sixty years ago, describing changes in the law of sellers' obligations regarding quality, Llewellyn expressed the relation between experience and law in the following powerful terms:

[In nineteenth-century common law,] [m]anufactured goods are handicraft articles, made by someone you know, and for the most local of markets.

Out of this we move gradually into a credit and industrial economy. ... Markets widen with improved transportation... . Sellers begin to build for good will, in wide markets .... The law of seller's obligation must change, to suit.

[W]ith the growing specialization of industry comes a complete dependence of the ... consumer upon the wares put into a national market. ... What is wanted is to protect the consumer dependent on a producer who is a stranger, or even anonymous. That needed protection is twofold: to shift the immediate incidence of the hazards of life in an industrial society . . . to a group which can distribute the loss; and to place the loss where the most pressure will be exerted to keep down fu-

16. Fish, Don't Know Much About the Middle Ages: Posner on Law and Literature, 97 YALE. L.J. 777 (1988). 
ture losses. ... Under such an ideal system of law the loss would lie ultimately where it belongs, on the consumers of the article concerned, en masse, in competition with other articles each carrying its own true costs in human life and effort. ${ }^{17}$

This passage brilliantly describes the change that occurred virtually without aid of statute in the common law of product liability, a change not fully realized until a few decades after Llewellyn wrote. ${ }^{18}$

Note that this common law is no longer the common law of laissez faire and personal markets; common law analysis has changed under the impulse of changing markets. It is not just that particular common law rules have changed in response to new market conditions; that this will occur - give or take a few decades of interim injustice is central to the argument of those who prefer it to other forms of government intervention. Rather, the change to note is the change in the basic terms of reference for the common law rules. From the assumption that ordinarily the law will be doing justice between two individuals dealing "individually, in a face-to-face, closed, stable group" 19 the law moved to considerations of loss distribution and social welfare, to placing loss "ultimately where it belongs, on the consumers of the article concerned en masse." 20 The common law now is typically described as a regulatory system with distributional effects; presenting it as still generally premised in laissez faire is quaint at best.

That today's common law, in some respects at least, appears to be making common cause with today's public (regulatory) law is hardly surprising, given the societal changes worked by the industrial revolution. The judges who shape it live in a world strikingly different from that of their eighteenth- and nineteenth-century predecessors, and have been educated to the ways of this world, not their predecessors'. They live not only with mass distribution, mass advertising, faceless transactions, and numerous middlemen, but also with a much heightened experience of interdependence. Ours is a world of enhanced specialization and resulting mutual reliance, and one that understands that it is that way. That legislatures moved against diffuse forms of environmental harm sooner than did common law courts may be ascribable to the innate conservatism of courts, the retarding influence of precedent, the relative antiquity of judges' education, the passive and reactive characteristics of judicial action, or limitations on standing or remedy characteristic of judicial action. That legislatures moved at all, however, is best ascribed to our collectively enlarging perceptions of the impact of our behaviors on planet earth - percep-

17. K. Llewellyn, Cases and Materials on the LaW of Sales 204, 341-42 (1930). (1989).

18. See Priest, Strict Products Liability: The Original Intent, 10 CARdozo L. Rev. 2301

19. K. LlewellyN, supra note 17, at 204.

20. Id. at 342 . 
tions judges will eventually share, if they do not already share them, and that will move the common law in the same manner as changing markets moved the law of sales. So one may believe that we are not talking only about New Public Law but, more simply, about new law, and the means for its formation.

If there is anything to this, if the more important phenomenon is the changing ground rather than the changing law, then rather than look at the New Deal statutes and their progeny as such, we might better focus on the struggles that engendered them. Sunstein is not alone in treating the New Deal as a magic moment that gave rise to "the administrative state," and he gives a very persuasive account of the emergence of these laws as a response to a series of failures of market ordering under common law. (Markets, he argues, not only cannot be expected to respond to certain problems; they capture and tend to perpetuate preferences traceable to prior failures and injustices.) Yet his focus on the rhetoric of the New Deal tends to deny the reader a sense of the continuity in the political struggles to which the New Deal was merely a culmination.

Although the great eruption of American national government occurred in the 1930s response to the Depression, the battle with the common law and laissez faire began in the states after the Civil War. It was during this time that our economy became national and industrial, and the failures of laissez faire thinking and the common law to respond to those developments - notoriously, the carnage of the workplace, but also the changing character of manufacture and distribution - became self-evident. Thus, for example, the development of workers' compensation statutes, already referred to; these statutes which may be seen either in traditional common law laissez faire terms, as an attempted redistribution of property from bakers to their employees, or in a wholly different light - as a response to problems of collective action occasioned by the changing character of the relevant markets. Thus, the 1930s' reversal on substantive due process capped an argument about the proper role of government that had been ongoing for half a century; much of the federal legislation of the New Deal (unemployment insurance, for example) may be seen principally as a response to collective action problems among the states in achieving programs that had been on the political agenda for years. ${ }^{21}$ Striking as it is that we seem to be reliving those battles today, Sunstein would be the more powerful if he acknowledged that, on the level of theory, he plays a role considerably older than that of FDR. He is playing Holmes 22 to his Chicago colleagues' Peckham.

21. Stewart Mach. Co. v. Davis, 301 U.S. 548 (1937).

22. See, e.g., Schlemmer v. Buffalo, Rochester \& Pittsburg Ry. Co., 205 U.S. 1, 12 (1906). 
III.

Market ordering, Sunstein persuasively shows, not only cannot be expected to respond to certain problems; it captures and tends to perpetuate the results of prior failures and injustice. Moreover, although Sunstein does not develop this point, the important characteristics of markets change over time, as the technologies of manufacture, transportation, and communication change. While the common law has demonstrated some capacity to follow these shifts, it has lagged several decades behind, responding to the contours of some prior state of play. Politics - collective action - is precisely the means we can employ to overcome these difficulties although it, too, is susceptible to them. If, as the darker proponents of public choice theories tend to do, one saw only politics' susceptibilities, our prospects would look fairly bleak. If instead one believes that politics sometimes produces the results that the public would or should actually choose, then the challenges are threefold: to find some means of distinguishing the good from the bad, to find governmental structures that will tend to express those preferences rather than the products of self-interest, and to design implementing regulations likely to be successful in securing those preferences once identified. Sunstein sees those challenges as worthy and capable of being met.

The first of these problems is a compound of the failures of market ordering and a problem of moral philosophy. One means for identifying an actual collective preference, that Sunstein repeatedly employs, is to see how market ordering might be expected to fail, and then determine whether the legislative response can be understood as a likely corrective to those failures. Much legislation can be so understood; examples include legislation that requires employers to provide safety information, or constrains abuse of public goods (air, water, etc.), or seeks to avoid discriminatory behaviors built on prior regimes now understood to have been unjust (for example, segregation), or establishes conventions regarding common social behavior, such as driving. This is a highly useful test, but one suspects not an infallible one. Among the examples Sunstein frequently invokes of laws that respond to failures of market ordering are the laws favoring "high culture" coverage in broadcast media. Although he presents an appealing picture of individuals who themselves watch "Wheel of Fortune" yet understand the need for the public to have "Live from Lincoln Center" available to all, it would not be difficult to tell this story as one in which rich, high-taste people appropriate public funds to satisfy their personal preferences. ${ }^{23}$

That Sunstein does not credit the selfish explanation is a reflection

23. T. Odendahl, Charity Begins at Home: Generosity and Self Interest Among the Philanthropic Elite (1990). 
of the way in which the problem of moral philosophy enters in. The "goodness" of some results, such as diversity in programming that will expose audiences to higher culture, invites the thought that at some level it is popularly wished, or at least invites indifferences to whether it is or not. It ought to be, because it is good. As it happens, I share that judgment about the good (as I suppose many academics do), and many others on which Sunstein's analyses to some extent rest - for example, that a law favoring the weaker elements of society is more likely to be just than one empowering the already mighty, or that it is good to promote autonomy in the process of preference formation, or that overcoming the effects of prior injustice is a necessary end of law. Nonetheless, these propositions rest outside the issues about the effects of market ordering, and rigorous justification of them would itself be a major intellectual undertaking. That is not the undertaking of this book; Sunstein does not develop a theory for identifying the good, but presents the moral views he holds essentially as premises generally shared in our society. Readers who do not share them are unlikely to find the argument persuasive on that score.

A more general way of describing this problem is to note that at times Sunstein seems quite ambivalent about the place of collective choice as a justification for governmental action. This is so without regard to those contexts (speech suppression, racial discrimination) in which we might be said collectively to have agreed in our Constitution that some apparently collective choices about outcomes could not be legitimated. Consider, for example, the regulation of risk: shall we prohibit FDA approval of food additives that have any carcinogenic effect, however slight? Is it regulatory failure to require operating nuclear power plants to meet risk assessments that (to the extent such figures can be calculated) are thousands of times more demanding than those demanded of electricity sources employing coal or oil fuels? Both choices could be thought to proceed from a sort of innate human inaccuracy in risk assessment; we tend to be very sensitive about food supply relative to other risks, and we respond much more emphatically to large-scale disaster or its potential than to the prospect of incremental harms (coal) or geopolitical threats (oil). Although these tendencies might be manipulated in political campaigns, I find little reason to think that either the food additive policy or the current level of risk regulation required of nuclear power plants are other than the product of genuinely collective choice - and they appear likely to endure despite the public's awareness of its "error" and the resulting costs. This leads us to the uncomfortable position that Sunstein and I know what the good is and the public does not - or, perhaps, will not - and if the result of that is regulatory failure that has to be corrected, then we have departed from democracy. And we have done so not because democratic process has been perverted by faction, or threatens to destroy a structural protection of the citizenry on which 
we have collectively agreed, but because the public cannot be trusted, because some of us know the good better than others of us.

Republicanism is a partial accommodation to this idea; Madison thought the election of representatives not only would avoid the problems of mass judgment and tend to control faction, but also would tend to place governmental decisions in the hands of the well-educated, who could be relied upon to subdue at least the larger excesses of momentary public zeal. Even that accommodation has its risks, and those risks are heightened if we undertake to act in cases in which some might think even the accommodation has failed to protect us against public excesses. Ordinarily Sunstein recognizes these problems. In particular, he presents himself as a republican, not an autocrat, and claims that he need not resolve the question of "the good" because his book addresses the functions of judges and administrators and (as I would agree) it is not appropriate for them to try to resolve this question (p. 73). They should respect collective political judgments, subject, perhaps, to some concern for distortions of the political process. One sometimes regrets that Sunstein does not always hold himself to the same constraint.

A similar problem emerges regarding the taxonomy of regulatory functions that Sunstein builds as part of his justification for regulation. Although Sunstein's taxonomy has acknowledged and inevitable parallels to Judge Stephen Breyer's taxonomy of regulatory failures, ${ }^{24}$ Sunstein's emphasis on the achievement of ends outside the strictly economic - promoting diversity of tastes, advising redress of prior injustice - gives it a persuasive richness. He identifies eight general ends for which regulation may be undertaken, all but one frequently if not invariably justifiable in terms of the ends to be sought: response to market failure (pp. 48-55), ${ }^{25}$ public-interested redistribution of resources (pp. 55-57), achievement of collective desires and aspirations (pp. 57-60), ${ }^{26}$ promotion of diverse experiences and preferences (pp. 60-61), reduction of social subordination (often associated with prior unjust legal regimes) (pp. 61-64), the reduction of undesirable preferences (the wish for addictive drugs, for example) (pp. 64-67), the prevention of outcomes that may prove irreversible and harmful to future

24. S. BREYER, supra note 5.

25. Here Sunstein invokes and persuasively explains the familiar problems of monopoly, collective action, coordination (on which side of the road shall we drive?), inadequate information, and externalities.

26. It is under this heading that Sunstein explains that "people seem to favor regulation designed to secure high-quality broadcasting even though their consumption patterns favor situation comedies." P. 58; see text accompanying supra note 23 . While the particular example may be questionable, a general characterization that associates this with collective action problems is more persuasive: it is not hard to imagine preferences people actually have, but would not wish to satisfy "unless they are sure that others will be bound as well." P. 58. Energy conservation programs or recycling programs, which involve community commitments to sacrifices that might seem pointless on an individual basis, are examples. 
generations (pp. 67-69), and (the bad apple) achievement of interest group transfers (pp. 69-71). Sunstein's examples are richer under some headings than under others; the explanations how market ordering cannot be expected to achieve these ends are clear and generally persuasive in supporting his judgment that (save for the last category) regulation seeking these ends not only can be explained, but also can often be justified under an attractive theory of desirable government function.

How is one to distinguish a public-interested redistribution of resources from an interest group transfer? How can one tell appropriate collective desires and aspirations from those that will interfere with either the desirable promotion of diverse experiences and preferences, or the reduction of social subordination the public or its representatives previously unjustly chose? How do we know if the prevention of outcomes that may prove irreversible and harmful to future generations - implementation, say, of the Endangered Species Act - or the reduction of "undesirable" preferences serves public ends or merely permits a faction to impose its will on the public? Sunstein flags the questions as difficult, and uses examples that, on the whole, are appealing to our desire to further the ends he identifies. "Theory and facts must be assembled to explain why (for example) regulation of broadcasting, public support for the arts, environmental controls and antidiscrimination statutes are public-regarding whereas various banking controls and agricultural subsidies are simple responses to the power of self-interested private groups - if indeed these are the appropriate conclusions" (p. 70).

One way to answer these questions is to look at outcomes: are the winners those that an interest group transfer theory would lead one to expect, or not? Indeed, that is the implicit mechanism of much of Sunstein's persuasion: laws favoring economically or socially subordinated groups, future generations, and, less clearly, green spaces are not the outcomes to be expected from interest-group transfers; that theory must strain to explain them against simpler and more persuasive accounts of civic virtue. He briefly suggests a few other means for distinction, but in the end escapes rigorous inquiry by invoking the limitation of $h i s$ interests to questions of interpretation and the limitation of judicial and agency interests to positions that accept the publicspirited character of legislation. Invoking Lochner, he argues, "[t]he task of interpretation calls for sympathetic engagement with the modern regulatory state, not for the use of principles conspicuously rejected by the rise of regulation" (p. 73). He has demonstrated that regulations can be, and often are, adopted for public ends; he finds that sufficient to command that courts and agencies, on the whole, presume that they are.

An ensuing chapter, "How Regulation Fails," seeks to develop this 
taxonomy by reference to experience, to understand whether we have achieved what we "wanted," and, if so, whether we achieved it at a price we ought to have been willing to pay. It is an essentially anecdotal and inconclusive analysis - one that, on the whole, candidly acknowledges the difficulty of any such inquiry and the limitations of this one. Sunstein begins with a list of important changes that have occurred in the wake of regulatory statutes: health gains from pollution reduction, restoration of fish and bird habitat, lives saved by seatbelts, reduced driving speeds and other auto safety changes, social changes resulting from legal measures against discrimination, and so forth. He continues with an impressive list of associated costs (not all for the same changes), many of which are outstandingly high: we may have spent $\$ 632$ billion to produce pollution reductions that could have been achieved for one fifth that figure; some of the most important pollution problems remain unresolved; responsible agencies seem incapable of acting on more than a few problems, which may not be the most important of those from which they could choose; and sometimes (as in the discrimination context recently) enforcement is simply lacking. All Sunstein intends to show by this, and he does claim to have shown it, is that "even when it is possible to identify a good reason for statutory intervention, governmental regulation may not be successful" (p. 83).

In assessing success or failure, however, Sunstein does not acknowledge the problems created for such assessments by the tension between what seems best described as the product of collective choice and what Sunstein regards as the "good." Perhaps the problem of enforcement effort presents the clearest example. Much as I would like to believe the contrary, it seems most reasonable to view the elections of Jimmy Carter, Ronald Reagan (twice), and George Bush as the repeated expression of an actual public preference to put in the White House a President committed to less regulation. Regulatory failure that results from political choice hardly suggests that regulation must or ordinarily would fail to counter the results of market ordering, or even that it could do so only at a cost inordinately higher than any foreseeable benefit; it suggests that we are choosing not to regulate. The real failures, from the perspective of Sunstein's announced struggle against the forces of minimal government, are only those that are necessary - those that result from interest-group transfers masquerading as regulation, from inevitable and permanent imbalance of cost and benefit, ${ }^{27}$ or the like. "Failures" that result from

27. It bears noting that a number of the problems Sunstein raises are likely transitory. He notes, correctly, that regulation has often been put in place for new sources only, without regard for the possible tendency to keep old, bad sources in use for periods beyond what might otherwise have been anticipated, and in that way to slow the course of progress. P. 92. Nonetheless, "grandfathering" is a traditional means of selling new ideas in politics and may well be preferable to other means of accommodating the interests of those most affected by new measures and 
the workings of an acceptable political process should be excluded from the count.

IV.

In choosing to focus on the success of agency regulation rather than on issues of agency structure and in eliding the issues of collective action and the good, Sunstein ultimately obscures what in my judgment are the two principal problems we face in constructive attention to government today. The first is the problem of governmental size; the second is our need for a means of theorizing about human behavior in politics that can embrace humanity's innate collective drives at the same time as it theorizes about its individualistic ones, and without reducing the one to the other.

Madison also saw (and for a time brilliantly accommodated) the importance of the problem of size in constructing effective government. Finding governmental structures that will tend to express "public" preferences (that is, either the actual preferences of the public, or the good), rather than the products of narrow self-interest, is the problem of republicanism, as Madison defined it. Sunstein has for some time shown himself to be among those who believe Madison had this problem right - designing government to defeat or at least diminish and contain the power of faction. ${ }^{28}$ Madison, however, was designing the institutions at the very head of government power, in a government that was neither very large nor very powerful. In the same way that the shift from face-to-face transactions over widely comprehendible goods to anonymous chains-of-transaction in goods of extraordinary complexity has transformed the law of sales and product liability, the shift from a face-to-face national government to one of mammoth bureaucracies in every quarter must transform the way we imagine government. A government of millions, acting under the oversight of presidential, congressional, and judicial offices that are themselves large bureaucracies, presents quite different problems for the civic engineer than a government whose leadership population approximates the town meeting. Sunstein is aware of the difficulties, agrees that they must be addressed, and expresses some hope for constructive resolution. Yet the book chiefly addresses the relationship between the judiciary and the agencies of government, while faction predominantly

perhaps well placed to block them; over time, if at less than ideal speed, change occurs that market ordering would not have secured.

One might also see the very high initial cost of pollution controls as a possibly transitional phenomenon. Commitment in that direction may spur innovation, alter social attitudes, and so forth, promising lower costs for the future; and some of the benefits of controls today may be measured in property damage, illnesses, and deaths that do not occur in the future. To the extent these results ensure today's costs can be regarded as a sort of capital investment, not properly assessed against current income only.

28. E.g., Sunstein, Beyond the Republican Revival, supra note 2, at 1542-64. 
makes itself felt in the agencies via their relations with their other two, more political overseers, or via internal means those relations tend to promote.

The issue about human nature is this: We know that economic analysis is premised on models that employ a simplified and impoverished account of human rational self-interest, as atomistic individuals who invariably seek personal gain. Emotion becomes not an expression of, but a distortion of, human character. Altruism, self-sacrifice, and collective behavior are to be explained as the products of strange tastes or other odd calculations about personal gain - that is, actions within the system of that model, and not the products of a competing, coexisting aspect of humanity. One may witness in history many phenomena that can be explained much more simply as the expression of collective aspects of our being than as odd calculations of strictly personal gain. If we characteristically express our individuality in the market, as we surely do, we characteristically express the collective elsewhere - in the tribe, the church, the community. The impoverishment of the economic model lies precisely in its failure to account in a convincing way for that aspect of our character that is the most central to politics. Political organization is the means by which we express our collectivity. ${ }^{29}$

Since people engaging in politics are fully human, they sometimes do act as the economic model would suggest; they are capable, and often drawn, to act in ways that seek personal gain rather than collective good. Yet economic analyses of politics that highlight the opportunities for self-dealing, or the possibilities of thus explaining ostensibly collective action, err in failing to credit the possibility of alternative explanations. Here one confronts a series of paradoxes or difficulties rooted in the juncture between our incapacity to escape the context in which we act and our ability to influence the context in which we will be. Understanding that political action may be selfinterested or collective in character, or perhaps a mix of the two that, in Madison's terms, men are not angels - we may appropriately take some defensive measures against the possibility that the ostensibly collective will in fact prove self-serving for some smaller, yet powerful group. Yet the more we admit that ostensibly collective action may be self-regarding, the more we invite self-regardingness as an acknowledged, in some sense legitimate, aspect of political behavior. At the limit, if we simply contend that all political behavior is inevitably selfregarding, we create enormous difficulties for ourselves, of the classic prisoners' dilemma sort. In a world that universally views political

29. Cf. Shaviro, Beyond Public Opinion and Public Interests: A Study of the Legislative Process as Illustrated by Tax Legislation in the 1980s, 139 U. PA. L. REV. 1 (1990); Pildes \& Anderson, Slinging Arrows at Democracy: Social Choice Theory, Value Pluralism, and Democratic Politics, 90 Colum. L. Rev. 2121 (1990). 
action as self-regarding, even if you and I understand that that is not the whole story, insuperable obstacles arise to achieving any outcome that is not a mutually advantageous "deal" for the winners in the economic sense. But we cannot escape some self-regardingness (along with some communitarian expression), because we cannot escape being who we are; utopian communities equally deny the fullness of human nature and fall apart. ${ }^{30}$ Finding and defending the middle ground here, too, seems to me to be a way of describing the battle that Sunstein is fighting.

It would be easier, of course, writing about this possessed with the knowledge we have all been denied, if I had in hand the theoretical structure that would account for both parts of our being. Bruce Ackerman has made a start with the distinction he proposes between "normal" and "constitutional" politics; ${ }^{31}$ whether or not one agrees with the particulars by which he identifies their competing realms, his recognition that we are capable of both selfish and other-regarding behavior, and consequent proposition that some political events are as collective judgments outside the ordinary domain of political action, mark an important intellectual step. Sunstein attempts no similar framework.

Just as the marketplace for goods has changed in ways that have compelled reorientation of law - public and private - the arena of politics has been changing in ways that doubtless contribute to the spirit of reexamination and skepticism that seems to characterize the current day. The political world has become considerably more bureaucratic and impersonal than it was a century or two ago. The individual now faces not only giant, distant corporations in the national economy, but also giant, distant government - with millions of civil servants organized in an unspeakably complex structure, more than 20,000 in the bureaucracy of Congress, nearly as many attached to the presidency itself, and a similarly overstuffed judiciary. Maintaining the citizen's position in the changing political context is the analog to the problem of maintaining the consumer's position in the changing economic market. Not the subject of Sunstein's book, although he certainly recognizes the problem, it could be thought the largest problem public law faces in digesting our recent changes.

The problem of legislative history may serve as an illustrative example, both of the difficulties introduced by the mixed character of our political behavior and of the problems introduced by the size and complexity of contemporary government. What use may appropriately be made of legislative history is, naturally enough, one of the issues Sunstein confronts in the statutory interpretation part of his work. His treatment is brief, ahistorical and hence acontextual, presented as an

30. G. Orwell, ANimal Farm (1946).

31. E.g., Ackerman, Constitutional Politics/Constitutional Law, 99 YALE L.J. 453 (1989). 
aspect of how we might best search for the appropriate meaning of a statute as enacted, and generally skeptical about using legislative history because of possibilities it will be manipulated by pressure groups not able to prevail on language, to serve self-interested ends. The paragraphs following present the problem longitudinally, in ways that may illustrate some of the themes I have been trying to develop here. ${ }^{32}$

We might begin around the turn of the century, when laissez faire ideas and the common law were dominant but the economy and the character of various markets had already begun to change in important ways. Dominant judicial ideas at the time were that statutes were intrusions on the common law, that ought to be resisted - narrowly construed, or found offensive to Due Process if they interfered unjustifiably with market ordering. Courts paid no more attention to the history of a statute than to the history of a contract. Legislatures responded more rapidly than the courts to the changes in the character of markets - to the failures of market ordering to achieve widely shared visions of political justice. Given judicial attitudes of that time, legislators had no reason to expect their reports and debates to be of much significance other than influencing other legislators. Judges, dealing only and narrowly with words, produced results that appeared to misunderstand statutory purpose and ignore political realities. This generated sharp responses. Most fundamental were the strong and ultimately prevailing criticism of the judicial performance as antidemocratic and, as important, the first stages in the establishment of the regulatory state - the creation of governmental bodies other than courts that could do court-like work and could be relied upon to carry out the ends that the people, through their legislatures, had politically chosen.

The period conventionally bounded by the Supreme Court's decision in United States v. American Trucking Association Inc., 33 brought a series of changes. Judges, responding to criticism about their obstruction of popular will in the construction of statutes, became more and more comfortable immersing themselves in the political history of statutes. These developments are sometimes presented as a search for specific meaning, but initially appear to have been directly responsive to the critique of earlier practice - a means of self-education regarding political purpose, to reduce the chance of misunderstanding the drives that produced the legislative outcomes. Leading commentators stressed the importance of using statutes as a generative source of lawpolicy within the common law, of building on rather than resisting legislative judgments in fashioning the general body of law. American

32. Some of the ideas in the paragraphs following are also developed in Strauss, Relational Readers of Intransitive Statutes: Agency Interpretation and the Problem of Legislative History, CHI.-KENT L. REV. (forthcoming 1990).

33. 310 U.S. 534 (1940). 
Trucking capped these developments not long after "substantive due process" had been repudiated as well. The two developments generally are not tied, but both represent the same impulse: judicial recognition of political judgment as a superior source of law, of the senior status of the legislature.

The repudiation of judicial policymaking following the substantive due process decisions seems also to have produced a change of emphasis respecting statutory interpretation. Justice Stone, a pro-statute progressive in the 1920s and 1930s, would write about the judicial function of creating a unified body of law out of common law and statute, recognizing the superior claim of the legislature; ${ }^{34}$ his view embodied a relatively strong judicial role, and one that would suggest more interest in general political purpose than in particularities of meaning. The Justices who joined the Court in the New Deal period, on the whole, accepted a more junior, atomistic role for themselves. They saw it as their responsibility to discern the particulars of congressional judgment: that led to quite detailed appraisals of legislative history. Judges did not seek just to understand political impulse, from which it might be possible to build a responsive legal order; they looked for the specific directions on the particular issue that might be implicit in the statute.

Yet as judges focused with greater energy on questions of detail, the legislature was changing in ways that added to the perils of such specific inquiries. The development perhaps the most prominent in the recent arguments about return to text-based interpretation was legislators' and others' growing awareness that legislative materials were being used for interpretive purposes after enactment, as well as (and perhaps more than) for persuasive and explanatory purposes during the enactment process. Increasingly, judges' awareness that reports may be written or remarks made in the hopes of influencing them has produced understandable hesitation to rely on these materials. Relatedly, the growth of the congressional bureaucracy has changed the character of Congress' working process in ways that bring these materials into question. Legislators spend less time legislating, less time in face-to-face dealings with one another, and have become more reliant on their expanding staffs; this further undercuts any notion that the conventional materials are the persuasive and explanatory documents they appear to be.

Finally, and particularly in the regulatory context, the character of the legislative enterprise has changed. Congress less frequently issues instructions directly to citizens, and more frequently orders government agents, in greater or lesser detail, to administer a given set of policies. $^{35}$ This inserts a third reference point into the statutory equa-

34. See Stone, supra note 8.

35. See Rubin, Law and Legislation in the Administrative State, 89 Colum. L. REV. 369 
tion; it is no longer a matter only of discerning the meaning that might have been chosen by Congress (that less frequently decides) or understood by the citizen (who is less frequently addressed). An official reader with special responsibilities and a continuing set of political as well as legal relationships with the Congress and the President interprets the text on a continuing basis.

These developments certainly mandate further change in judicial response, but it ought not to be simply a return to textualism. The judge's need for information about the political impetus for the measure before her, information which statutory words alone are unlikely to supply, remains unaltered. Congress' steadily increasing use of agencies rather than courts to administer statutes itself suggests the need for sympathetic implementation. A judicial approach that signals lack of interest in even the broadest dimensions of the political history and direction of legislation will only aggravate that usage - as well as underscore, in a democracy, the problematic character of such an approach. That, one would have thought, was the judicial lesson of the New Deal.

Moreover, the introduction of the third reader, the agency, and its character as a continuing and political player in statutory administration, suggest ways in which the legislative history process may be reconceived, even if we concede that it no longer represents much of a deposit of persuasion and explanation within the Congress. ${ }^{36}$ The very fact of increased reliance on staff work and committee work within Congress suggests the possible fruitfulness of regarding the documents of legislative history as an agreed record of that process. The existence of the agency as a continuing administrator, in a continuing oversight relationship with the Congress, also implies that we may be wrong to think that the principal aim of making such records is to influence the courts.

We are not about to undo the governmental changes we have experienced in the past century, given their origin in reaction both to the changing conditions of an industrial, national economy and to judicial resistance to democratic impulse. The third reader, then, is a fact that will not go away. Its presence and the nature of its relationships with the political branches change the context for statutory interpretation in a manner text-exclusive approaches cannot accommodate. Those approaches imagine statutes rather unlike the common law, at least as we now understand the common law; the statute-as-text is generally seen as a vessel of fixed meaning, with the disputes focused on the

(1989); Strauss, Legislative Theory and the Rule of Law: Some Comments on Rubin, 89 ColuM. L. REV. 427 (1989).

36. Note, however, that because all players in the legislature know how material may be used, and are long-term participants in the legislative enterprise, what materials appear where in the legislature history is likely to reflect political strength and degree of political commitment, not just individual manipulation of the system. 
reference points for determining that meaning - words that are read, or historical purposes or intents that were held. But statutes no longer have meaning so much as they invite others to supply it; those supplying meaning are caught up in a complex of continuing political relationships that is expected to influence the meaning that is supplied. The judicial function has become one more of supervision of the workings of this process - that is, administrative law - than of fixing concrete meanings. ${ }^{37}$ In this process, like the common law, meaning emerges over time, in response to the stimulus of events.

Of course, we have not escaped from ourselves. Like the judges and the legislators before them, agency officials may express their "rational self-interest maximizer" side as well as their collectivist selves. Legislators and presidents acting to oversee their continuing administration, employing the characteristic forms of political oversight, may act for faction or for nation. These possibilities cannot be escaped; in hoping they can be shaped or controlled, we have always to remember that they will also be lurking in the behavior of whatever next set of institutions or safeguards we design.

What we notice about legislative history in this context are some characteristics that seem to argue for its continued use. To the extent it is a record at all, it is a record of what occurred at the time Congress took its constitutionally characteristic action of legislating. While it embodies some admixture of manipulative, potentially factional nonlegislation in it, what we now need to consider is that Congress is subject to manipulative, potentially factional influences at all times when it is overseeing as well as when it is legislating. Legislative history is associated with the legislating; devaluing it is, in some respects, devaluing legislating in relation to what else Congress does. Further, unlike much oversight activity, the legislative history is public and generally accessible, and engages Congress as a whole. When one begins to see the problem of giving statutes meaning as a relational rather than as a discrete process, the availability of context-setting reference points against which to assess the course of that relationship is not to be denigrated.

Perhaps most important, once the legislative moment has passed, the legislative history provides a haven of "law" (as well as political instruction) for the administrative agency against the continuing politics of the oversight process. Often present during the legislative process, the agency does not view the legislative history issue as providing an optional means of acquiring information about an incidental problem. The legislative history it worries about is its legislative history, perhaps more properly just its history: it would be an integral part of its daily experience whether courts concerned themselves with it or not. This history is inseparable from the statute the agency adminis-

37. Chevron v. Natural Resources Defense Council, 467 U.S. 837 (1984). 
ters, and the particular and continuing responsibility the agency has. It sets understandings with the agency's oversight committees, which are forces far more powerful in its daily life than the courts, and would do so whether the courts paid attention to this history or not. It provides a framework of expectation likely to be enforced, a basis for common understanding with committee staffs whose working lives parallel those of the civil servants at the agency; and it sets constraints on those relationships by establishing a set of baselines against which the moment's effort at oversight may be measured.

This is not the place to develop fully ideas about the uses of legislative history once we begin to see statutes in a relational light. For present purposes, I want only to suggest that this shift in paradigm represents an important sea-change in the regulatory state, and that we cannot think about such issues as statutory interpretation for the regulatory state without taking this shift into account. We need to examine our arguments about interpretive techniques, to guard against the implicit assumption that statutes have fixed meanings, rather than meanings that develop over time under the administration of agencies and the supervision of courts. Today, as in Sunstein's book, questions of changing statutory meaning are presented as if the only issue were the rather dramatic question of "obsolescence" or "middle age." But that presentation continues to see statutes as rocks, lacking the plasticity of the common law; it fails to find in them generative force for new common law, ${ }^{38}$ or a way of adapting the judiciary to what is our new mode of providing flexibility and change in law.

V.

Finally, although Sunstein's "rights revolution" is not troubling in one descriptive sense, in another it raises a set of issues with which I think he has not adequately dealt. Plainly, we recognize, and embody in expanded notions about standing to challenge agency action, ${ }^{39}$ that regulatory legislation often creates expectations in its intended benefi-

38. See Pound, supra note 7.

39. Sunstein is not as clear as he might be in recognizing that this generally expanded notion of standing is a judicial, rather than statutory, artifact. See pp. 210-17. The drafters of the Administrative Procedure Act in 1946 gave no hint that they anticipated the Supreme Court's 1970 holding that their language conferred general standing on statutory beneficiaries. Association of Data Processing Serv. Orgs. v. Camp, 397 U.S. 150 (1970). In the context of that time one could believe only that the drafters meant to save the "private attorney general" idea that had been developed concerning some particular statutes authorizing review at the behest of persons aggrieved. E.g., Associated Indus., N.V. v. Ickes, 134 F.2d 694 (2d Cir.), vacated as moot, 320 U.S. 707 (1943). This observation does not render the Court's 1970 holdings erroneous for one who accepts, as I do, that judicial interpretation is appropriately informed by the possibilities of language when interpretation occurs. The words can be understood as the Court understood them, and the argument for doing so is essentially Sunstein's. Nonetheless, seeing this as a judicial artifact may itself serve to highlight some of the problems involved in describing the person aggrieved's claim as a "right" in the fullest sense. Cf. Lujan v. National Wildlife Fedn., $110 \mathrm{~S}$. Ct. 3177 (1990). 
ciaries that could be described as "rights." The problem is whether these descriptively are - or normatively ought to be regarded as fully the same "rights" as one usually means when talking about the right, for example, not to be compelled to incriminate oneself or to secure federal judicial relief under section 1983 of the Civil Rights Act for action taken under the color of state law that deprives one of "rights." Sunstein often treats regulatory expectations as equivalent to these individuated claims, yet we may be permitted to doubt, for example, whether a section 1983 action could be brought for their violation. ${ }^{40}$ Indeed, one sees in the tensions beneath the surface of recent decisions on standing and the application of section 1983 fairly strong intimations of a return to a "legal rights" theory of judicial review with, however, the rights now expanded to embrace the "new property." 41

The distinction suggested here, one Sunstein does not discuss, is the distinction Holmes developed in a holding still central to the domain of procedural due process. Holmes contrasts official action by which claimants are "exceptionally affected, in each case upon individual grounds" (procedural due process requires some kind of a hearing) with action having a more general impact, for which citizens' "rights are protected in the only way they can be in a complex society, by their power, immediate or remote, over those who make the rule" (no hearing is required) ${ }^{42}$ One need not agree with Holmes that only political controls are relevant in the latter context to understand the force behind the impulse to differentiate the individual case (where politics cannot be expected to help, where issues are likely to be bipolar rather than polycentric, and so forth) from the general one. Citizen "power, immediate or remote, over those who make the rule" is present in the settings Sunstein wishes to capture by his "rights revolution"; politics is inevitably and appropriately involved. That suggests possible bases and needs for differentiation that warrant exploration.

Sunstein suggests one possible response in discussing the distinction between agency action and agency inaction. This distinction played an important role in the Supreme Court's decision in Heckler $v$.

40. See Wilder v. Virginia Hosp. Assn., 110 S. Ct. 2510 (1990), in which a bare majority of the Court permitted a $\S 1983$ action to be brought by health care providers to challenge state reimbursement practices under Medicaid. While some language in the opinion suggests a notion of "right" broader than the individualized claims for fair payment for services actually rendered that were at stake in that case, Justice White's switch to the conservative majority in Lujan $\mathbf{v}$. National Wildlife Fedn., 110 S. Ct. 3177 (1990), two weeks following, and the emphasis in that opinion on the differences between political and judicial controls over administrative action suggests that that is not a likely direction for the Court.

41. Monaghan, Federal Statutory Review Under Section 1983 and the APA, 91 Colum. L. REV. (forthcoming 1991).

42. Bi-Metallic Inv. Co. v. State Bd. of Equalization, 239 U.S. 441, $445-46$ (1915). Cf. Lujan, $110 \mathrm{~S}$. Ct. at 3191. 
Chaney ${ }^{43}$ that agency decisions not to enforce are presumptively nonreviewable. Such priority-setting decisions resemble Holmes' second, more political context in their polycentricity and their usual reference to the budgetary and executive processes. For "traditionally disadvantaged groups, public aspirations, and collective action problems," Sunstein notes, political controls are unlikely to be successful (p. 220).

The argument echoes Justice Stone's famous justifications for strict judicial scrutiny of some constitutional issues, set out in footnote 4 of his opinion in United States v. Carolene Products Corp. ${ }^{44}$ Stone, however, was not supporting rights for the powerless that the powerful would not share. He thought the judiciary should keep the political process responsive, and did not argue that the judiciary should weight that process toward the downtrodden; the judiciary was to uphold the individual liberties of all citizens (a role that, to be sure, might be especially important for the disadvantaged), not just the liberties of the insular minorities.

Past experience with such administrative law developments as the paper hearing strongly suggests, as should not be surprising, that the powerful readily appropriate legal innovations undertaken in the name of the underrepresented. ${ }^{45}$ In the context of individual rights, we accept that cost (although affirmative action is proving a puzzle); for matters that are at root political, it is at least questionable whether we can afford to go past the point of enhancing the integrity of our explicitly political processes. Sunstein does not put his recommendations to the hard test of seeing how they might be used by the "other side." Moreover, it may be that judicial protections have proved available in the past precisely because courts have tended to act in contexts in which we do not openly concede a significant, legitimate role to politics. Where political controls are available to the citizen seeking to influence administrative action, the question of allocating power between the courts and the political branches requires attention not only to the relative competencies of each, but also to the enhanced risk that the courts' actions will themselves be politicized. The latter risk is particularly striking for an enterprise like Sunstein's proposed canons, with their implicit reliance on objectified and essentially apolitical administration. Yet Sunstein's instincts are to extend judicial action significantly into central political realms.

Thus, consistent with his earlier writings on the subject, Sunstein argues for significant judicial oversight of congressional and agency judgments respecting agency prioritizing. In Young v. Community

43. 470 U.S. 821 (1984).

44. 304 U.S. 144,152 n.4 (1938).

45. See, e.g., Kennecott Copper Corp. v. EPA, 462 F.2d 846 (D.C. Cir. 1972); Portland Cement Assn. v. Ruckleshaus, 486 F.2d 375 (D.C. Cir. 1973), cert. denied, U.S. 921 (1974). 
Nutrition Institute, ${ }^{46}$ the Supreme Court accepted a Food and Drug Administration judgment that its governing statute did not require it to undertake rulemaking to define tolerances for every poisonous or deleterious substance that might unavoidably occur in food. This was an error in Sunstein's view, because statutory syntax ("the Secretary shall promulgate regulations") suggests an obligation to act - independent of any consideration of agency resources, independent of political controls that could be exercised over such decisions, and independent of the effect judicial oversight might have on agency resources and decisionmaking (pp. 162-63).

Similarly, Sunstein believes Heckler v. Chaney ${ }^{47}$ (in which the Court announced a presumption against judicial review of agency inaction) was in error because it depended so strongly on the common law baseline. Although here Sunstein acknowledges "plausible reasons to treat agency inaction in a different way from agency action," he insists that the courts must be available to say whether "the agency has acted responsibly"; he does not give much weight to the alternative (political) fora in which that question may be asked, the resource costs to the agency of permitting that question to be (repeatedly) asked in court by its opponents (powerful as well as weak), or - especially, in my judgment - the possibilities of judicial politicization inherent in a question so programmatic in character, a question that would involve the judiciary so closely in executive judgment (p. 220). The problem, then, is whether one can maintain the predominantly apolitical character of the courts that seems so central to the Madisonian vision Sunstein wants to revive, without paying closer attention to Holmes' division between the worlds of political and legal controls than Sunstein cares to essay.

Note that this division is not the same as the distinction between regulatory subjects and regulatory beneficiaries. Holmes' distinction was developed in a case in which those relegated to political process were regulated entities, property owners who had been affected by tax reassessments applicable across the board; thus, the result put them in the same position as the beneficiaries of the municipal services to be underwritten by the additional tax revenues. It is an attraction of Sunstein's approach that tends to put regulated and regulatory beneficiaries on an equal "procedural claim" footing; and it is certainly not my purpose to endorse the argument, which has recently resurfaced in the Supreme Court, ${ }^{48}$ that the regulated have stronger claims to judicial hearings than regulatory beneficiaries in any particular procedural context. The problem with Sunstein's approach is the way in which it tempts us to overlook the differences between particular procedural

46. 476 U.S. 974 (1986).

47. 470 U.S. 821 (1985).

48. E.g., Lujan v. National Wildlife Fedn., 110 S. Ct. 3177 (1990). 
contexts (the decision whether or not to commit resources to a project, as against the decision on a project to which resources have been committed) in assessing the appropriateness of procedural claims; for both the regulated and the regulatory beneficiary, judgments about priorities and resource allocations are contexts that, as Holmes' argument suggests, must be left to political controls.

VI.

Wrestling with the place of statutes in law suggests the struggles over the relative place of the judiciary, legislature, and executive in government. The recent rounds of judicial formalism in reading statutes respond to real changes in government and its institutions. At the same time, the response threatens to enlarge executive authority at the expense of both Congress and the courts. Turning away from legislative politics and a view of courts as integrators of the legal order permits a centralization of effective authority for government that should seem particularly troublesome in a democracy characterized by enormous government. If the size and ambition of our government are not mistakes - and Sunstein makes that case well - then we need to address its work in ways that both enhance its opportunities for success, and promise restraints on its power. After the Rights Revolution is an important effort in that direction. 